\title{
Pengujian efek kualitas dan risiko keamanan pada intensi pembelian makanan dengan mediasi traceability
}

\author{
Hetty Karunia Tunjungsari* \\ Universitas Tarumanagara, Jl. Letjen S. Parman No. 1, Grogol, Jakarta Barat, 11470, Indonesia \\ hetty@fe.untar.ac.id \\ Kennedy Lianto \\ Universitas Tarumanagara, Jl. Letjen S. Parman No. 1, Grogol, Jakarta Barat, 11470, Indonesia \\ kennedy.lianto@gmail.com \\ Chairy Chairy \\ Universitas Presiden, Jababeka Education Park, Jl. Ki Hajar Dewantara, Cikarang Utara, Bekasi, \\ Jawa Barat, 17530, Indonesia \\ chairy@president.ac.id \\ *Penulis Korespondensi
}

Submitted: Oct 13, 2021; Reviewed: Oct 14, 2021; Accepted: Nov 12, 2021

\begin{abstract}
There are several consumer considerations in buying and consuming food such as the quality and safety of the food and traceability of the food itself. This study examines the effect of food quality and perception of food risk on purchase intention. We also examine mediating effect of traceability in the influence of quality and safety on consumer purchase intentions. The survey was conducted online to obtain data consisting of 100 fast food consumers. The research hypothesis testing was carried out using SmartPLS statistical software. The results showed food quality and perception of food risk have significant influence on purchase intention. However, there was no mediating effect of traceability in the influence of food quality and safety on consumer purchase intentions. This research theoretically expands the literature in the field of consumer behavior, particularly related to food marketing. The results of this study can practically be used as a basis for formulating food marketing strategies, especially related to steps that can be used to maintain food quality, safety, and traceability as an effort to increase consumer purchase intentions.
\end{abstract}

Keywords: food quality; food traceability; perception of food risk; purchase intention

Abstrak: Terdapat sejumlah pertimbangan konsumen dalam membeli dan mengonsumsi makanan seperti meliputi kualitas dan keamanan makanan serta traceability dari makanan itu sendiri. Penelitian ini menguji efek kualitas makanan dan persepsi atas risiko keamanan makanan pada intensi pembelian. Kami juga menguji efek mediasi traceability dalam pengaruh kualitas dan keamanan pada intensi pembelian konsumen. Survei dilakukan secara online untuk mendapatkan data responden yang terdiri dari 100 orang konsumen makanan cepat saji. Pengujian hipotesis penelitian dilakukan dengan menggunakan software statistik SmartPLS. Hasil penelitian menunjukkan bahwa kualitas dan persepsi atas risiko makanan memiliki pengaruh signifikan pada intensi pembelian. Namun demikian, tidak terdapat efek mediasi traceability dalam pengaruh kualitas dan keamanan makanan pada intensi pembelian konsumen. Penelitian ini secara teoretis memperluas literatur dalam bidang perilaku konsumen, khususnya terkait dengan pemasaran makanan. Hasil penelitian ini secara praktis dapat 
dijadikan dasar penyusunan strategi pemasaran makanan, khususnya terkait dengan langkah-langkah yang dapat digunakan untuk mempertahankan kualitas, keamanan, serta traceability makanan sebagai upaya untuk meningkatkan intensi pembelian konsumen.

Kata kunci: intensi pembelian; kualitas makanan; persepsi atas risiko keamanan makanan; traceability makanan

\section{PENDAHULUAN}

Indonesia merupakan negara dengan masyarakat yang beragam, mulai dari suku, budaya, agama hingga persepsi masyarakat atas berbagai hal, dapat pula berbeda satu dengan yang lainnya. Persepsi adalah proses bagaimana seseorang memilih, mengatur, dan menginterpretasikan masukan informasi untuk menciptakan gambaran keseluruhan yang bermakna (Kotler \& Keller, 2012). Sementara itu budaya merupakan seperangkat sikap, nilai, keyakinan, dan perilaku yang dimiliki bersama oleh sekelompok orang, tetapi berbeda untuk setiap individu, dikomunikasikan dari satu generasi ke generasi berikutnya (Matsumoto, 1996). Setiap masyarakat memiliki persepsi dan budaya yang berbeda-beda, terutama dalam menentukan suatu kualitas dan keamanan.

Pentingnya variasi budaya dalam pilihan makanan diakui dalam konteks negara, seperti misalnya di wilayah Eropa (Askegaard \& Madsen, 1998). Perbedaan yang sering dibuat di Eropa adalah antara negara-negara yang terletak di wilayah utara atau pusat, misalnya Inggris dan Skandinavia serta keamanan pangan dan masalah etika misalnya tentang tata cara makan (Pettinger et al., 2004). Atas dasar budaya yang ada, diperkirakan bahwa konsumen di negara-negara yang berbeda mungkin memiliki kekhawatiran yang berbeda tentang aspek kualitas dan keamanan makanan dan merasakan kegunaan dari ketertelusuran (traceability). Misalnya, konsumen di negara-negara Mediterania umumnya dianggap lebih khawatir tentang kualitas makanan, sedangkan konsumen di negara-negara Eropa Utara umumnya dianggap mementingkan risiko sehingga mereka lebih peduli dengan keamanan pangan (Kearney, 2010).

Kualitas dan keamanan adalah dua elemen penting dalam pengambilan keputusan konsumen terkait dengan pilihan makanan (Grunert, 2005). Pelanggan yang datang untuk mencari makanan tentu ingin membeli makanan yang berkualitas. Menurut Kotler \& Keller (2012), masyarakat khususnya masyarakat di perkotaan akan memilih suatu makanan yang berkualitas serta aman untuk dikonsumsi. Lebih lanjut, Kotler \& Keller (2012) juga menyebutkan bahwa kualitas pada makanan adalah sesuatu yang sangat relatif dan beragam antara orang yang satu dengan yang lain. Penyeragaman kualitas baik itu rasa, ukuran, tampilan, maupun elemen lain yang membentuk suatu produk maupun layanan, merupakan faktor penting yang perlu diperhatikan setiap produsen. Hal ini diperlukan untuk menjaga kualitas produk serta mendapatkan kepuasan pelanggan. Walaupun persepsi atas kualitas yang ada di benak konsumen dapat saja memiliki perbedaan antara satu dengan yang lain, setidaknya terdapat satu standar umum yang minimal harus dipenuhi untuk masing-masing kategori produk maupun jasa.

Dalam konteks makanan, selain kualitas, keamanan untuk mengonsumsi makanan tersebut juga berpengaruh (Anwar, 2004). Meskipun tidak mudah untuk dilaksanakan, namun banyak upaya untuk meningkatkan higiene pangan dan kebersihan lingkungan, seperti peningkatan kualitas kesehatan sarana pengolahan pangan. Kesulitan tersebut disebabkan oleh beragamnya makanan yang dikonsumsi manusia dan bertambahnya tempat pengolahan. Isu ini merupakan persoalan yang semakin kompleks, dan juga merupakan tantangan yang harus dihadapi ke depan, karena di satu sisi masyarakat akan lebih peka terhadap permintaan pangan yang lebih berkualitas.

Sampai saat ini, penelitian yang membahas tentang persepsi konsumen dan tuntutan mengenai traceability makanan relatif masih terbatas. Terbatasnya jumlah penelitian yang telah dilakukan sejauh ini dikarenakan hanya difokuskan pada persepsi konsumen terkait dengan satu produk atau kategori produk tertentu (Dickinson \& Bailey, 2002). Penelitian yang dilakukan sejauh ini menunjukkan bahwa konsumen memiliki sedikit gagasan tentang apa yang dimaksud dengan traceability (Giraud \& Amblard, 2003), serta kurang berminat pada aspek traceability (Molnár et al., 2010). Oleh karena itu, sering kali muncul pendapat bahwa pemberian informasi tentang aspek-aspek teknis traceability dapat meningkatkan kepercayaan konsumen.

Traceability biasanya dikaitkan dengan risiko makanan dan isu-isu keselamatan yang berpotensi dapat digunakan untuk memastikan keamanan pangan dan kualitas makanan (Giraud \& Amblard, 2003). 
Sebagai contoh, traceabilty mungkin menjadi alat yang ampuh untuk membantu dalam menetapkan keaslian makanan, dan untuk memeriksa bahwa makanan yang dibuat produsen merupakan makanan yang layak. Penelitian sebelumnya telah menunjukkan bahwa konsumen mungkin akan tertarik ketika terkait dengan jenis jaminan kualitas dan keamanan traceability makanan (Yuan et al., 2020, Verbeke $\&$ Ward, 2006).

Menyikapi perubahan perilaku konsumen dalam mengonsumsi berbagai produk dan jasa, khususnya makanan, sejak terjadinya pandemi COVID-19 di akhir 2019 lalu, peneliti memandang pentingnya aspek traceability sebagai salah informasi yang perlu disediakan oleh pemasar untuk mendapatkan kepercayaan pelanggan. Persepsi atas risiko yang dapat ditimbulkan, terkait dengan COVID-19, dapat memengaruhi bagaimana konsumen membeli dan mengonsumsi makanan. Konsumen yang peduli dengan bahaya yang ditimbulkan oleh COVID-19 akan mengonsumsi makanan yang lebih sehat untuk meningkatkan sistem imunitas tubuh mereka (Janssen et al., 2021). Oleh sebab itu, persepsi akan traceability makanan menjadi salah satu faktor penting yang dapat memengaruhi intensi pembelian konsumen. Penelitian ini bertujuan untuk menguji adanya peran mediasi persepsi akan traceability makanan dalam pengaruh kualitas dan keamanan makanan.

Kualitas makanan adalah karakteristik yang dapat diterima oleh konsumen, meliputi faktor eksternal berupa ukuran, bentuk, warna, konsistensi, tekstur, dan rasa (Potter \& Hotchkiss, 1995). Standar kualitas makanan sulit didefinisikan dan tidak dapat diukur secara mekanik, namun demikian, dapat dilakukan evaluasi berdasarkan nutrisi, bahan yang digunakan, rasa, serta penampilan produk. Pengaplikasian kriteria-kriteria tersebut pada setiap makanan cukup beragam, tetapi dapat disimpulkan bahwa sejumlah faktor yang memengaruhi pendapat seseorang terdiri dari usia, latar belakang budaya dan sosial, ekonomi, pengalaman masa lalu yang berkaitan dengan makanan, pendidikan dan pengetahuan ilmiah, serta emosi (Widjaja, 2009).

Menurut Margaretha \& Japarianto (2012), secara garis besar faktor-faktor yang memengaruhi persepsi konsumen dalam kualitas makanan meliputi warna, penampilan, porsi, bentuk, temperatur, tekstur, aroma, serta rasa. Agar tampilan makanan dapat terlihat menarik dan serasi, maka bahan-bahan makanan harus dikombinasikan sedemikian rupa supaya tampilannya juga dapat menumbuhkan intensi konsumen atas makanan. Berdasarkan kondisi ini, maka dapat dipahami bahwa makanan harus memiliki tampilan yang menarik saat disajikan karena penampilan dapat memengaruhi selera makan konsumen.

Penyajian makanan sudah ditentukan porsi standarnya yang disebut standard portion size. Di Indonesia, penggunaan istilah standard portion size relatif kurang dikenal di kalangan masyarakat luas, jika dibandingkan dengan istilah porsi gizi seimbang. Dalam Peraturan Menteri Kesehatan No. 41 Tahun 2014 (2014) Tentang Gizi Seimbang, telah diatur "panduan konsumsi makanan sehari-hari dan berperilaku sehat berdasarkan prinsip konsumsi aneka ragam pangan, perilaku hidup bersih, aktivitas fisik, dan memantau berat badan secara teratur dalam rangka mempertahankan berat badan normal bagi masyarakat Indonesia." Sebagai contoh, standar 1 porsi tempe adalah 2 potong sedang ukuran 50 gram, 1 porsi ikan adalah 1 potong ukuran 40 gram ikan segar, 1 porsi buah dapat berupa 1 potong pisang Ambon ukuran 50 gram atau 20 butir anggur, dan lain-lain. Dengan demikian, kualitas makanan juga ditentukan oleh porsi gizi seimbang dalam setiap penyajiannya.

Bentuk makanan dapat memainkan peranan penting dalam menciptakan daya tarik mata yang kemudian dapat menggugah selera makan. Sebagai contoh, untuk mendapatkan bentuk makanan yang menarik, dapat dilakukan pemotongan bahan makanan yang bervariasi, pengaturan makanan yang estetis di piring saji, penggunaan hiasan (garnish), dan lain sebagainya. Variasi temperatur makanan juga dapat memengaruhi rasa. Perubahan rasa manis pada sebuah makanan dapat ditemukan pada rasa yang lebih manis saat makanan tersebut masih hangat, di sisi lain, sup yang masih panas akan terasa kurang asin dibandingkan saat suhunya telah berangsur hangat. Selain itu, tekstur makanan meliputi halus atau kasar, cair atau padat, keras atau lembut, serta kering atau lembab juga dapat menimbulkan sensasi rasa yang berbeda saat dikonsumsi. Tekstur makanan juga dipengaruhi oleh tingkat kematangan makanan, misal daging yang dimasak terlalu lama akan menjadi alot, wortel yang kurang matang terasa keras saat digigit, dan cake yang kurang matang akan memiliki tekstur lembek di bagian tengah.

Hal berikutnya yang juga merupakan faktor penting dalam menentukan kualitas makanan adalah aroma yang ditimbulkan oleh makanan, sebagai contoh, masakan olahan seafood yang segar ditandai dengan aroma makanan yang tidak amis, cake akan menyebarkan aroma harum mentega, dan masakan dengan bumbu rempah-rempah akan memiliki aroma khas rempah-rempah yang digunakan. Terakhir, rasa makanan merupakan penentu utama kualitas makanan tersebut. Jenis rasa utama meliputi manis, 
asam, asin, dan pahit, dapat menjadi indikator kualitas suatu makanan baik berdiri sendiri maupun kombinasi dari beberapa rasa yang membentuk keunikan tertentu. Sebagai contoh, ikan dengan bumbu asam manis, sup asam pedas, yamin manis asin, hingga tumis pare yang mengandung rasa pahit memiliki kekhasan sendiri yang menunjukkan kualitas makanan tersebut.

Kualitas makanan dapat memengaruhi intensi pembelian oleh konsumen. Mattila \& Wirtz (2001) menyatakan bahwa kualitas makanan adalah penentu utama loyalitas pelanggan di restoran. Lebih lanjut, Grunert (2005) menyatakan bahwa kualitas makanan terkait dengan pilihan dan permintaan makanan konsumen. Abdullah et al. (2018) melakukan penelitian terkait intensi berkunjung kembali di restoran di Malaysia dan hasilnya menunjukkan bahwa kualitas makanan, kualitas pelayanan, dan kewajaran harga memengaruhi kepuasan pelanggan. Selain itu, kepuasan pelanggan juga mengarah pada intensi berkunjung kembali. Kualitas merupakan penentu utama dari intensi pembelian konsumen. Sejumlah penelitian sebelumnya membuktikan bahwa kualitas produk yang dirasakan dapat memengaruhi intensi pembelian baik secara langsung maupun melalui mediasi kepuasan (Cronin \& Taylor, 1992; Madu et al., 1995; Sweeney et al., 1999; Llusar et al., 2001).

Berdasarkan pembahasan mengenai kualitas makanan dan kaitannya dengan intensi pembelian pada bagian terdahulu, disusunlah hipotesis penelitian sebagai berikut.

H1: Terdapat pengaruh signifikan kualitas makanan pada intensi pembelian.

Keamanan pangan adalah kondisi pangan yang bebas dari unsur yang berbahaya bagi kesehatan, baik yang secara alami terdapat pada bahan pangan yang digunakan maupun yang sengaja atau tidak sengaja bercampur dengan pangan atau pangan olahan (Moehji, 2003). Saparinto \& Hidayati (2006) menyebutkan bahwa "keamanan makanan adalah kondisi dan upaya yang diperlukan untuk mencegah pangan dari kemungkinan cemaran biologis, kimia, dan benda lain yang dapat mengganggu, merugikan, dan membahayakan kesehatan manusia." Pangan yang aman serta bermutu dan bergizi tinggi sangat penting peranannya bagi pertumbuhan, pemeliharaan, dan peningkatan derajat kesehatan serta peningkatan kecerdasan masyarakat.

Seto (2001), di sisi lain, mendefinisikan keamanan pangan sebagai semua upaya yang dapat dilakukan untuk menghindari klaim berbahaya dari bahan makanan. Selain itu, Seto (2001) menyatakan bahwa keamanan pangan merupakan faktor terpenting dalam konsumsi dan ekspor pangan dalam negeri guna memenuhi kebutuhan nasional dan menghindari risiko kesehatan dari mikroorganisme dan senyawa. Hal ini dikarenakan interaksi antara toksisitas mikroba, toksisitas kimia, status gizi, dan keamanan pangan adalah masalah yang kompleks. Makanan yang tidak aman dapat mempengaruhi kesehatan manusia dan menyebabkan masalah gizi.

Kecemasan mengenai keamanan makanan meningkat pesat selama beberapa tahun terakhir, khususnya jika dikaitkan dengan pandemi COVID-19 yang terjadi sejak akhir 2019. Pada masa sebelumnya, negara-negara berkembanglah yang lebih banyak terkena penyakit akibat konsumsi makanan (World Health Organization [WHO], 2015). Risiko atas keamanan makanan dapat dijelaskan melalui analisis risiko dari sudut pandang bahaya yang ditimbulkan dari mengonsumsi suatu makanan tertentu. Bahaya timbul karena suatu peristiwa yang berkaitan dengan kegiatan atau proses, yang dapat menimbulkan konsekuensi negatif dan kemudian menjadi sumber risiko bagi lingkungan atau populasi yang mengkonsumsinya. Bahaya yang muncul dari konsumsi makanan dapat diklasifikasikan berdasarkan sumber risikonya, yaitu bahaya mikrobiologi, kimia, dan teknologi (Yeung \& Morris, 2001).

Sifat dasar masalah keamanan makanan adalah adanya informasi yang asimetri (Smith et al., 2015). Ketika terjadi asimetri informasi secara luas antara produsen dan konsumen, konsumen dapat membuat pilihan yang merugikan karena kekurangan informasi, yang menyebabkan inefisiensi mekanisme pasar. Secara umum, konsumen mengevaluasi kualitas suatu produk berdasarkan informasi karakteristik mutu dan keamanan produk, yang menjangkau konsumen dalam bentuk isyarat kualitas. Informasi ini didefinisikan dari perspektif permintaan konsumen sebagai atribut produk, yang diklasifikasikan ke dalam pencarian, pengalaman, dan atribut kepercayaan (Becker, 2000). Asimetri informasi ini kemudian dapat memunculkan risiko keamanan makanan, sehubungan dengan konsekuensi yang berpotensi berbahaya bagi konsumen.

Persepsi risiko konsumen dan dampaknya terhadap perilaku pembelian sangat relevan dengan masalah keamanan pangan. Persepsi risiko sebagai keyakinan tentang risiko yang dihadapi konsumen terhadap makanan yang dikonsumsinya (Costa-Font et al., 2008). Dalam penelitian terkait makanan, 
hasil rekayasa genetika menunjukkan bahwa persepsi risiko juga memengaruhi evaluasi konsumen terhadap makanan (Hudson et al., 2015). Saat konsumen merasakan risiko yang lebih tinggi dari suatu makanan, maka mereka akan menolak makanan tersebut (Chen \& Li, 2007; Zhang et al., 2018). Oleh karena itu, penelitian ini mengajukan hipotesis berikut.

H2: Terdapat pengaruh persepsi atas risiko makanan pada intensi pembelian.

Konsumen percaya baik keamanan maupun kualitas adalah faktor yang penting untuk makanan secara umum. Traceability dikaitkan tidak hanya untuk keamanan makanan, tetapi juga untuk kualitas makanan dan persepsi atas keamanan makanan di benak konsumen. Definisi traceability menurut Codex Alimentarius (2003) adalah kemampuan untuk melacak semua tahapan produksi, proses, dan distribusi. Uni Eropa mendefinisikan traceability secara lebih luas, mencakup kemampuan untuk melacak atau sejarah semua produk maupun item yang berhubungan dengan makanan yakni: makanan dan bahan makanan, hewan penghasil makanan, atau makanan dan bahan campuran atau campuran makanan.

UKessays (2018) menjelaskan bahwa traceability dapat dibagi menjadi dua bagian, yaitu internal dan eksternal. Dalam traceability internal mencakup informasi bahan baku, produk baik setengah jadi maupun produk akhir dari unit produksi atau unit pengolahan, dan hanya melibatkan satu pihak. Dalam traceability eksternal mencakup pergerakan produk dari jalur persepsi tertentu dan mungkin melibatkan banyak pihak. Traceability penting bagi konsumen karena mereka perlu mendapat kepastian akan produk pangan dengan atribut konsumsi yang diinginkan, aman dikonsumsi, dan bebas dari kontaminasi. Kesimpulannya, produk harus bebas dari kekhawatiran bagi konsumen. Oleh sebab itu, ketidakpastian dalam mencapai tujuan keamanan makanan dapat menyebabkan beberapa kemungkinan kerugian bagi konsumen.

Traceability makanan mampu menghasilkan aliran informasi keamanan yang berkelanjutan dalam rantai pasokan dengan mengintegrasikan atribut produk. Sistem ini tidak hanya dapat memberikan informasi kualitas dan keamanan, seperti asal dan proses manufaktur, tetapi juga berguna untuk memantau produksi dan distribusi pangan, mengidentifikasi masalah keamanan pangan, dan penarikan kembali produk makanan yang cacat (Regattieri et al., 2007). Traceability bukanlah alat untuk meningkatkan keamanan makanan, tetapi merupakan bagian dari sistem pengelolaan keamanan makanan. Secara teknis, sistem traceability terdiri dari beberapa metode penelusuran untuk mencatat perubahan materi properti dan operasi selama proses produksi suatu makanan (Gunawan et al., 2021).

Liu \& Niyongira (2017) mengemukakan bahwa keberadaan sistem traceability pada makanan dapat menawarkan lebih banyak transparansi kepada konsumen dalam pemahaman tentang seluruh proses dari produksi hingga penjualan dan merasakan makanan yang lebih aman. Dengan kata lain, sistem traceability merupakan cara yang efektif bagi konsumen akhir untuk menghindari risiko keamanan makanan. Sebagaimana diketahui, tujuan konsumen membeli makanan adalah untuk memperoleh produk pangan yang memiliki atribut konsumsi yang diinginkan, aman dikonsumsi, dan bebas dari kontaminasi, dan karena itu makanan harus bebas dari kekhawatiran bagi konsumen.

Informasi yang disediakan oleh traceability makanan mengurangi ketidakpastian konsumen tentang persepsi produk ke tingkat tertentu yang luas, dan dapat meningkatkan niat beli (Choe et al., 2009). Sejumlah penelitian perilaku konsumen dalam kaitannya dengan traceability bahan makanan mengungkapkan bahwa konsumen bersedia membayar mahal untuk makanan yang memiliki informasi traceability (Dickinson \& Bailey, 2002; Ortega et al., 2011; Wu et al., 2011; Zhang et al., 2012). Dengan demikian, disusunlah hipotesis 3 penelitian ini sebagai berikut.

H3: Terdapat peran mediasi traceability dalam pengaruh kualitas dan risiko keamanan pada intensi pembelian makanan.

Model penelitian dapat dilihat pada Gambar 1. 


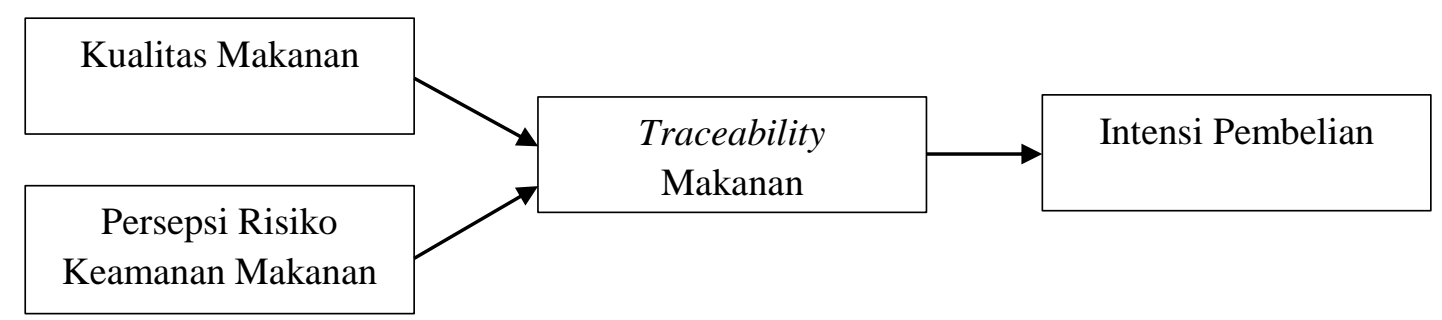

Gambar 1. Model penelitian

Sumber: Kajian literatur oleh peneliti (2021)

\section{METODE}

Populasi dalam penelitian ini adalah konsumen makanan restoran cepat saji yang berada di Jabodetabek. Teknik pengambilan sampel yang dilakukan dalam penelitian ini merupakan teknik non-probability sampling, dengan metode convenience sampling. Untuk memperoleh data, peneliti menyebarkan kuesioner secara online dengan mengirimkan tautan Google Form dalam pesan di Whatsapp, baik secara pribadi maupun melalui Whatsapp Group. Terdapat sebanyak 109 orang responden yang merespon, namun setelah dilakukan pengecekan atas kelengkapan jawaban diperoleh sebanyak 100 buah data yang dapat diolah lebih lanjut.

Instrumen yang digunakan dalam penelitian ini menggunakan instrumen pada sejumlah penelitian terdahulu. Rangkuman indikator untuk variabel yang diukur dalam penelitian ini dapat dilihat pada Tabel 1. Masing-masing indikator diukur dengan menggunakan Skala Likert 6 poin, mulai dari 1: "Sangat Tidak Setuju", 2: "Tidak Setuju", 3: "Kurang Setuju", 4: "Cukup Setuju", 5: "Setuju", dan 6: "Sangat Setuju". Penggunaan skala Likert 6 poin ini tujuannya adalah untuk mengurangi kecenderungan pilihan netral (nilai di tengah), karena beberapa peneliti berpendapat bahwa adanya pilihan netral menimbulkan bias atas penilaian responden (Mustafa, 2009). Dalam pengujian validitas dan reliabilitas instrument, telah diperoleh hasil yang menunjukkan bahwa seluruh indikator yang digunakan dalam penelitian ini telah valid dan reliabel. Selanjutnya, pengujian hipotesis dilakukan dengan menggunakan software statistik SmartPLS.

Pada bagian analisis validitas dan reliabilitas, terdapat 21 item total indikator untuk mengukur variabel kualitas makanan, persepsi keamanan makanan, traceability, dan intensi pembelian. Nilai AVE masing-masing variabel memiliki nilai di atas $0,5(>0,5)$ yang berarti valid (Hair et al., 2014). Hasil perhitungan loading factor menunjukkan terdapat 13 item indikator pada variabel intensi pembelian yang tidak memenuhi syarat validitas dan memiliki nilai di bawah $0,4(<0,4)$, sehingga dihapus dari model penelitian (Henseler et al., 2009). Dengan demikian, terdapat total 8 item indikator yang telah memenuhi syarat validitas konvergen karena memiliki nilai loading factor di atas $0,5(>0,5)$ serta validitas diskriminan yang menggunakan Heteroit-Monotrait Ration dan Cross Loadings (Ghozali, 2012). Nilai Composite Reliability dan Cronbach's Alpha keempat variabel juga telah memiliki nilai di atas 0,6 (>0,6), sehingga seluruh indikator telah reliabel (Nunan et al., 2020).

Tabel 1. Operasionalisasi variabel penelitian

\begin{tabular}{|c|c|c|}
\hline Variabel & Indikator & Sumber \\
\hline Kualitas makanan & $\begin{array}{l}\text { - } \quad \text { Makanan yang disajikan masih segar* } \\
\text { - Makanan dan minuman yang disajikan merupakan } \\
\text { makanan organik } \\
\text { - } \quad \text { Tingkat kematangan yang disajikan baik* } \\
\text { - Makanan dan minuman yang disajikan memiliki } \\
\text { rasa yang enak }\end{array}$ & Qin et al. (2010) \\
\hline $\begin{array}{l}\text { Keamanan } \\
\text { makanan }\end{array}$ & 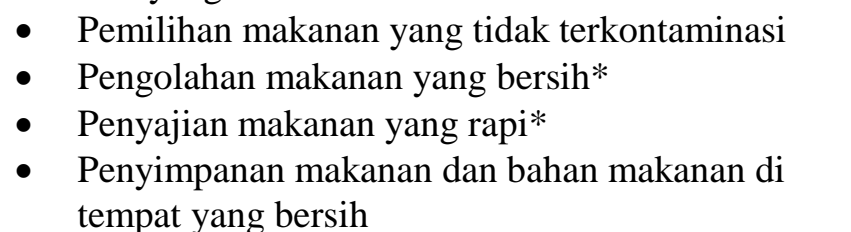 & $\begin{array}{l}\text { Fieldhouse } \\
\text { (1995); De } \\
\text { Jonge et al. } \\
\text { (2007); Slovic } \\
\text { et al. (2004) }\end{array}$ \\
\hline
\end{tabular}




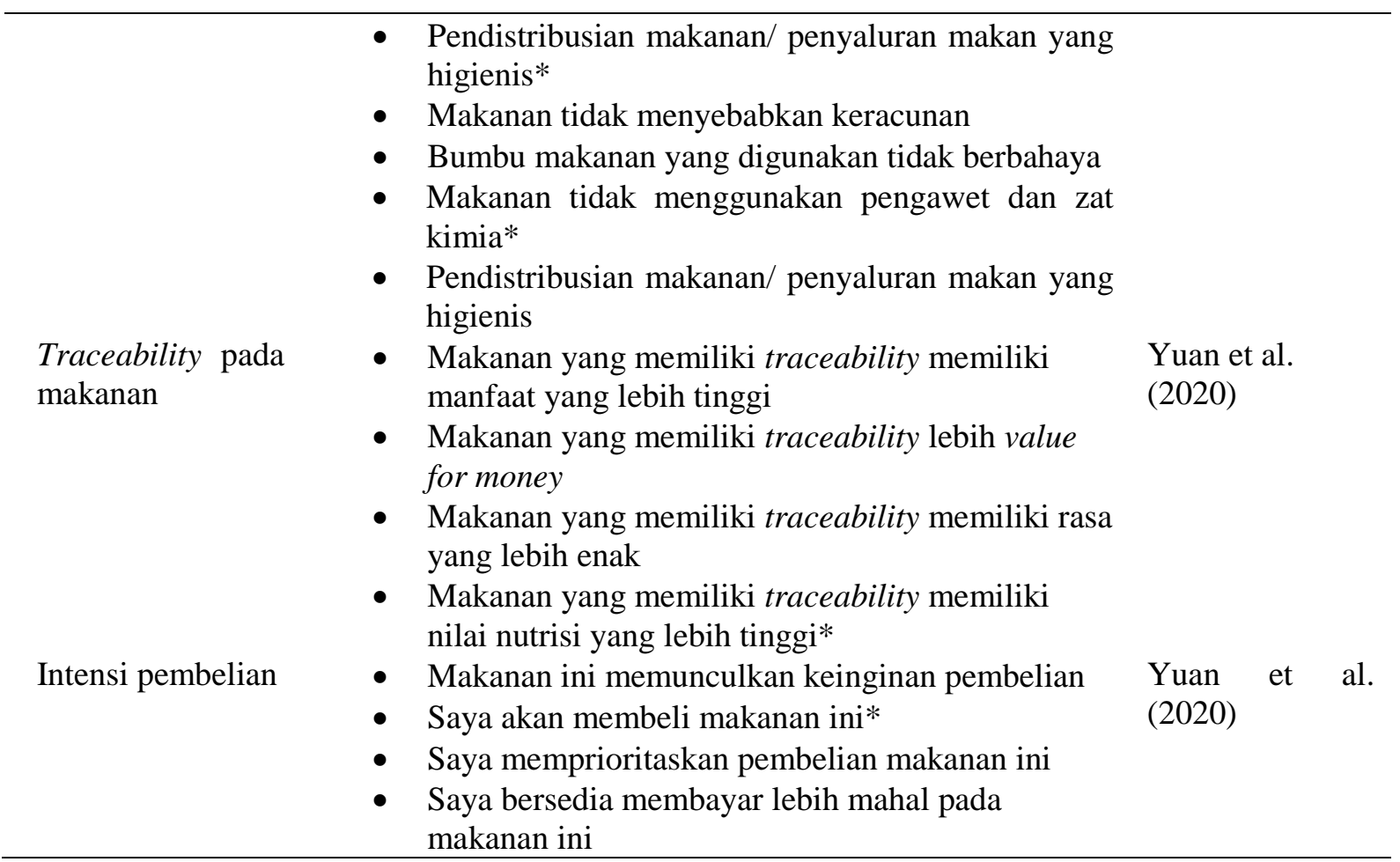

*Indikator yang valid dan reliabel

Sumber: Kajian literatur oleh peneliti (2021)

\section{HASIL DAN PEMBAHASAN}

\subsection{Hasil}

Responden dalam penelitian ini terdiri dari 57\% pria dan $43 \%$ wanita, dengan rentang usia dari umur 18 tahun hingga di atas 50 tahun. Mayoritas responden berusia antara 31 hingga 50 tahun (80\%), 29\% berusia antara 18 hingga 30 tahun, dan $20 \%$ berusia di atas 50 tahun. Berdasarkan latar belakang pendidikan, mayoritas responden merupakan lulusan S1 (50\%), 32\% lulusan SMA, 15\% lulusan S2, dan $3 \%$ lulusan S3. Seluruh responden berdomisili di seputar daerah Jabodetabek.

Hasil pengujian bootstrapping dapat dilihat pada Tabel 2 dan Gambar 2. Dari hasil pengujian ini, dapat disimpulkan bahwa hipotesis 1 dan hipotesis 2 yang diajukan dalam penelitian ini didukung oleh data secara statistik dengan nilai $p$-value lebih kecil dari $0.05(<0,05)$. Pengujian efek mediasi ditampilkan hasilnya pada Tabel 3 dan dapat dilihat bahwa nilai $p$-value lebih besar dari $0,05(>0,05)$. Dengan demikian, hipotesis 3 dalam penelitian ini tidak didukung oleh data karena memiliki $p$-value lebih besar dari $0,05(>0,05)$.

Tabel 2. Hasil pengujian bootstrapping

\begin{tabular}{lccc}
\hline & Path coefficient & T statistics & P values \\
\hline Kualitas makanan $\rightarrow$ Intensi pembelian & 0,117 & 2,226 & $0,026^{*}$ \\
$\begin{array}{l}\text { Persepsi risiko keamanan makanan } \rightarrow \text { Intensi } \\
\text { pembelian }\end{array}$ & 0,730 & 4,597 & $0,000^{*}$ \\
\hline
\end{tabular}

Sumber: Hasil olah data SmartPLS (2021) 


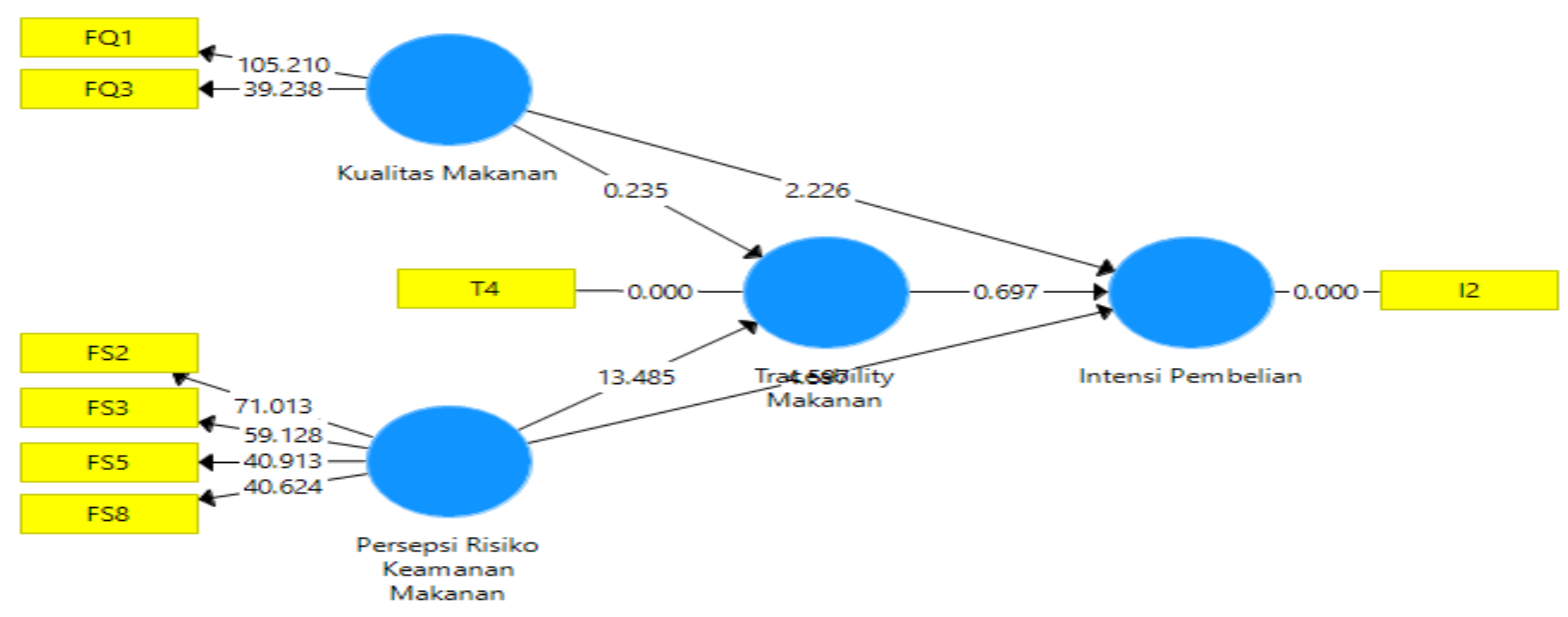

Gambar 2. Bootstrapping

Sumber: Hasil olah data Smart PLS (2021)

Tabel 3. Analisis mediasi

\begin{tabular}{lccc}
\hline & Path coefficient & T statistics & P values \\
\hline $\begin{array}{l}\text { Kualitas makanan } \rightarrow \text { Traceability makanan } \rightarrow \\
\begin{array}{l}\text { Intensi pembelian } \\
\text { Persepsi risiko keamanan makanan } \rightarrow \text { Traceability } \\
\text { makanan } \rightarrow \text { Intensi pembelian }\end{array}\end{array}$ & 0,001 & 0,139 & 0,889 \\
\hline
\end{tabular}

Sumber: Hasil olah data SmartPLS (2021)

\subsection{Pembahasan}

Hipotesis 1 dalam penelitian ini bertujuan untuk membuktikan adanya pengaruh kualitas makanan pada intensitas pembelian. Hasil penelitian menunjukkan adanya dukungan data pada hipotesis 1 secara statistik. Dengan demikian, dalam konteks restoran cepat saji, intensitas pembelian konsumen terbukti dipengaruhi oleh kualitas makanan. Hal ini mendukung penelitian terdahulu seperti yang dilakukan oleh Ortega et al. (2011) serta Kealesitse \& Kabama (2012) yang menunjukkan bahwa kualitas makanan sangat memengaruhi keputusan konsumen dalam membeli produk makanan. Saleem et al. (2015) mengemukakan bahwa pelaku industri yang bergerak di bidang makanan perlu meyakinkan konsumen bahwa mereka akan mendapatkan produk dengan kualitas yang tinggi karena kualitas makanan merupakan salah satu faktor penentu intensi pembelian.

Hasil pengujian hipotesis 2 penelitian ini membuktikan adanya dukungan data secara statistik pada dugaan adanya pengaruh persepsi atas keamanan makanan pada intensitas pembelian. Sebagaimana dijelaskan pula dalam penelitian terdahulu, diketahui bahwa keamanan makanan sangat penting dalam menentukan keputusan pembelian makanan (Kealesitse \& Kabama, 2012; Ortega et al., 2011). Konsumen umumnya memilih produk makanan yang aman dan berkualitas tinggi. Kekhawatiran konsumen tentang keamanan dan kualitas makanan cenderung memengaruhi intensi membeli makanan di masa yang akan datang. Penelitian terdahulu juga menunjukkan bahwa evaluasi akan isyarat kualitas produk, kualitas yang diharapkan/ dialami dari konsumsi suatu makanan, serta motif pembelian merupakan prediktor utama intensi pembelian suatu makanan (Saeed \& Grunert, 2014).

Pengujian hipotesis 3 dilakukan untuk membuktikan efek mediasi traceability makanan dalam pengaruh kualitas makanan dan persepsi atas keamanan makanan pada intensi pembelian. Hasil pengujian hipotesis 3 membuktikan bahwa tidak terdapat efek mediasi dalam pengaruh variabel independen pada variabel dependen. Masih sangat sedikit penelitian yang mengaitkan traceability makanan dengan intensi pembelian secara langsung maupun menguji efek mediasinya dengan variabel 
independen yang relevan. Namun demikian, traceability makanan terbukti memengaruhi persepsi konsumen atas nilai suatu makanan serta memengaruhi keputusan pembelian konsumen (Lu et al., 2016; Yuan et al., 2020). Tidak diperolehnya dukungan data secara statistik dalam penelitian ini dapat disebabkan oleh sejumlah faktor, seperti misalnya adanya kemungkinan kurangnya pemahaman responden akan pentingnya traceability makanan. Ketika konsumen memiliki pengetahuan yang memadai tentang kebutuhan dan produk yang mereka inginkan, hal ini akan berdampak pada meningkatnya efek traceability makanan pada nilai yang dirasakan oleh konsumen, yang pada akhirnya dapat memengaruhi intensi pembelian (Chaudhuri, 2000; Zaichkowsky, 1985).

\section{SIMPULAN DAN SARAN}

Berdasarkan pemaparan pada bagian terdahulu, dapat disimpulkan bahwa dalam konteks restoran cepat saji, responden memandang kualitas makanan dan persepsi atas keamanan makanan sebagai faktor penting yang menentukan intensi pembelian mereka. Di sisi lain, traceability makanan pada restoran cepat saji tidak dapat memediasi pengaruh kualitas makanan dan persepsi atas keamanan makanan pada intensi pembelian. Secara teoretis, implikasi hasil penelitian ini memperluas penelitian terdahulu dalam bidang perilaku konsumen di industri makanan, khususnya terkait faktor-faktor yang memengaruhi intensi pembelian konsumen pada restoran cepat saji. Hasil penelitian ini mendukung adanya bukti bahwa kualitas dan persepsi atas makanan merupakan faktor penting yang memengaruhi intensi pembelian konsumen.

Implikasi praktis dari hasil penelitian ini dapat dimanfaatkan oleh pengelola restoran cepat saji, bahwa dengan mengeksplorasi persepsi konsumen mengenai kualitas makanan serta risiko keamanan makanan, mereka dapat menyusun strategi pemasaran alternatif yang bervariasi (berkaitan dengan fitur produk), harga (termasuk diskon dan harga diskriminatif), promosi dan komunikasi (termasuk metode untuk menginformasikan atau membujuk tentang risiko mengkonsumsi makanan tertentu), serta sistem distribusi dan logistik (termasuk jaminan kualitas dan traceability).

Keterbatasan penelitian ini salah satunya adalah tidak dilakukannya skrining berkaitan dengan pemahaman konsumen akan manfaat traceability makanan. Adanya penelitian terdahulu yang membuktikan bahwa konsumen dengan pemahaman yang lebih tinggi mengenai produk dan traceability makanan memiliki intensi pembelian yang lebih tinggi memunculkan ide penelitian lanjutan untuk memasukkan variabel pemahaman konsumen ke dalam model penelitian untuk pengujian lebih lanjut.

\section{REFERENSI}

Abdullah, D., Hamir, N., Norfezah, Md., Jayaraman, K., Rostum, M., \& Mardhiah, A. (2018). Food quality, service quality, price fairness, and restaurant re-patronage intention: The mediating role of customer satisfaction. International Journal of Academic Research in Business and Social Sciences, 8(17), 211-226. https://doi.org/10.6007/IJARBSS/v8-i17/5226

Anwar. (2004). Pendidikan kecakapan hidup (Life skill education). Alfabeta

Askegaard, S., \& Madsen T. K. (1998). The local and the global: Exploring traits of homogeneity and heterogeneity in European food cultures. International Business Review, 7(6), 549-568. https://ideas.repec.org/a/eee/iburev/v7y1998i6p549-568.html

Becker, T. (2000). A framework for analysing public and private food quality policy: Meeting consumer requirements? In Becker, T. (Ed.) Quality Policy and Consumer Behaviour in the European Union, 91-110. FAIR CT95-0046. Vauk. Kiel. 280 p

Chaudhuri, A. (2000). A Macro analysis of the relationship of product involvement and information search: The role of risk. Journal of Marketing Theory and Practice, 8(1), 1-15. http://www.jstor.org/stable/40470212

Chen, M., \& Li, H. (2007). The consumer's attitude toward genetically modified foods in Taiwan. Food Quality and Preference, 18(4), 662-674. https://doi.org/10.1016/j.foodqual.2006.10.002

Choe, Y. C., Park, J., Chung, M., \& Moon, J. H. (2009). Effect of the food traceability system for building trust: Price premium and buying behavior. Information Systems Frontiers, 11(2), 167-179. https://doi.org/:10.1007/s10796-008-9134-z 
Codex Alimentarius. (2003). Code of Practice for Fish and Fishery Products. www.codexalimentarius.net

Costa-Font, J., Garcia-Gonzalez, A., \& Font-Vilalta, M. (2008). Relative income and attitudes towards long-term care financing. The Geneva Papers on Risk and Insurance: Issues and Practice, 33(4), 673-693. http://www.jstor.org/stable/41953003

Cronin Jr, J. J., \& Taylor, S. A. (1992). Measuring service quality: A reexamination and extension. The Journal of Marketing, 56(3), 55-68. https://doi.org/10.2307/1252296

De Jonge, J., Van Trijp, H., Jan Renes, R., \& Frewer, L. (2007). Understanding consumer confidence in the safety of food: Its two-dimensional structure and determinants. Risk analysis: An official publication of the Society for Risk Analysis, 27(3), 729-740. https://doi.org/10.1111/j.15396924.2007.00917.x

Dickinson, D. L., \& Bailey, D. (2002). Meat traceability: Are US consumers willing to pay for it? Journal of Agriculture and Resource Economy, 27(2), 348-64. https://digitalcommons.usu.edu/cgi/viewcontent.cgi?article=1239\&context=eri

Fieldhouse, P. (1995). Food and nutrition customs and culture. Chapman \& Hall

Ghozali, I. (2012). Aplikasi analisis multivariabel dengan program IBM SPSS 20. BP Universitas Diponegoro

Giraud, G., \& Amblard, C. (2003). What does traceability mean for beef meat consumer?. Sciences Des Aliments, 23(1), 40-46. https://sda.revuesonline.com/gratuit/SDA23_1_040_046.pdf

Grunert, K. G. (2005). Food quality and safety: Consumer perception and demand. European Review of Agricultural Economics, 32(3), 369-391. https://econpapers.repec.org/article/ouperevae/v_3a32_3ay_3a2005_3ai_3a3_3ap_3a369-391.htm

Gunawan, I., Vanany, I., \& Widodo, E. (2021). Typical traceability barriers in the Indonesian vegetable oil industry. British Food Journal, 123(3), 1223-1248. https://doi.org/10.1108/BFJ-06-2019-0466

Hair Jr, J., Sarstedt, M., Hopkins, L., \& G. Kuppelwieser, V. (2014) Partial least squares structural equation modeling (PLS-SEM): An emerging tool in business research. European Business Review, 26(2), 106-121. https://doi.org/10.1108/EBR-10-2013-0128

Henseler, J., Ringle, C. M., \& Sinkovics, R. R. (2009). The use of partial least squares path modeling in international marketing. In Advances in International Marketing, 20(March), 277-319, https://doi.org/10.1108/S1474-7979(2009)0000020014

Hudson, S., Roth, M. S., Madden, T. J., \& Hudson, R. (2015) The effects of social media on emotions, brand relationship quality, and word of mouth: An empirical study of music festival attendees. Tourism Management, 47(April), 68-76. https://doi.org/10.1016/j.tourman.2014.09.001

Janssen, M., Betty, P. I. C., Hristov, H., Pravst, I., Profeta, A., \& Millard, J. (2021). Changes in food consumption during the COVID-19 pandemic: Analysis of consumer survey data from the first lockdown period in Denmark, Germany, and Slovenia. Frontiers in Nutrition, 8(March), 1-20, https://doi.org/10.3389/fnut.2021.635859

Kealesitse, B., \& Kabama, I. O. (2012). Exploring the influence of quality and safety on consumers' food purchase decisions in Botswana. International Journal of Business Administration, 3(2), 90-97. http://dx.doi.org/10.5430/ijba.v3n2p90

Kearney J. (2010). Food consumption trends and drivers. Philosophical transactions of the royal society of London. Series B, Biological Cciences, 365(1554), 2793-2807. https://doi.org/10.1098/rstb.2010.0149

Kotler, P., \& Keller, K. L. (2012). Marketing management. Prentice-Hall

Liu, A., \& Niyongira, R. (2017). Chinese consumers food purchasing behaviors and awareness of food safety. Food Control, 79(September), 185-191. https://doi.org/10.1016/J.FOODCONT.2017.03.038

Llusar, J. C. B., Zornoza, C. C., \& Tena, A. B. E. (2001). Measuring the relationship between firm perceived quality and customer satisfaction and its influence on purchase intentions. Total Quality Management, 12(6), 719- 734. https://doi.org/10.1080/09544120120075334

Lu, J., Wu, L., Wang, S., \& Xu, L. (2016). Consumer preference and demand for traceable food attributes. British Food Journal, 118(9), 2140-2156. https://doi.org/10.1108/BFJ-12-2015-0461

Madu, C., Kuei, C., \& Lin, C. (1995). A comparative analysis of quality practice in manufacturing firms in the US and Taiwan. Decision Sciences, 26(5), 621-635. https://doi.org/10.1111/j.15405915.1995.tb01443.x 
Margaretha, S., \& Japarianto, E. (2012). Analisa pengaruh food quality \& brand image terhadap keputusan pembeli roti kecik Toko Roti Ganep's di Kota Solo. Jurnal Manajemen Pemasaran, 1(1), 1-6. https://docplayer.info/41008687-Jurnal-manajemen-pemasaran-vol-1-no-1-2012-1-6-1.html

Matsumoto, D. (1996) Culture and psychology. Pacific Grove, CA: Brooks/ Cole

Mattila, A. S., \& Wirtz, J. (2001). Congruency of scent and music as a driver of in-store evaluations and behavior. Journal of Retailing, 77(2), 273-289. https://doi.org/10.1016/S0022-4359(01)00042-2

Moehji, S. (2003). Ilmu gizi 2. Papas Sinar

Molnár, A., Gellynck, X., Vanhonacker, F., \& Verbeke, W. (2010). Towards the development of innovative strategies for traditional food chains in the EU. Int. J. Food System Dynamics, 1(1), 1-12. https://doi.org/10.18461/ijfsd.v1i1.112

Mustafa, Z. E. Q. (2009). Mengurai variabel hingga instrumentasi. Graha Ilmu

Nunan, D., Malhotra, N. K., \& Birk, D. F. (2020). Marketing research: Applied insight. Pearson

Ortega, D. L., Wang, H. H., Wu, L., \& Olynk, N. J. (2011). Modeling heterogeneity in consumer preferences for select food safety attributes in China. Food Policy, 36(2), 318-324. http://www.sciencedirect.com/science/article/pii/S0306-9192(10)00144-2

Peraturan Menteri Kesehatan Nomor 41 Tahun $2014 . \quad$ (2014). https://peraturan.bpk.go.id/Home/Details/119080/permenkes-no-41-tahun-2014

Pettinger, C., Holdsworth, M., \& Gerber, M. (2004). Psycho-social influences on food choice in Southern France and Central England. Appetite, 42(3), 307-316. https://doi.org/10.1016/j.appet.2004.01.004

Potter, N. N., \& Hotchkiss, J. H. (1995). Food Sciences. Chapman and Hall

Qin, H., Prybutok, V. R., \& Zhao, Q. (2010). Perceived service quality in fast-food restaurants: Empirical evidence from China. International Journal of Quality \& Reliability Management, 27(4), 424-437. http://doi.org/10.1108/02656711011035129

Regattieri A., Gamberi, M., \& Manzini, R. (2007). Traceability of food products: General framework and experimental evidence. Journal of Food Engineering, 81(2), 347-356. http://doi.org/10.1016/j.jfoodeng.2006.10.032

Saeed, F., \& Grunert, K. (2014). Expected and experienced quality as predictors of intention to purchase four new processed beef products. British Food Journal, 116(3), 451-471. https://doi.org/10.1108/BFJ-10-2011-0262

Saleem, A. R., Bangash, N., Mahmood, T., Khalid, A., Centritto, M., \& Siddique, M. T. (2015). Rhizobacteria capable of producing ACC deaminase promote growth of velvet bean (Mucuna pruriens) under watermstress condition. International Journal of Agriculture and Biology, 17(3), 663-667. https://doi.org/10.17957/IJAB/17.3.14.788

Saparinto, C., \& Hidayati. D. (2006). Bahan tambahan pangan. Kanisius

Seto, S. (2001). Pangan dan gizi ilmu teknologi industri dan perdagangan internasional. Fakultas Teknologi Pertanian

Slovic, P., Finucane, M. L., Peters, E., \& MacGregor, D. G. (2004). Risk as analysis and risk as feelings: Some thoughts about affect, reason, risk, and rationality. Risk Analysis, 24(2), 311322. https://doi.org/10.1111/j.0272-4332.2004.00433.x

Smith, B.A., Ruthman, T., Sparling, E., Auld, H., Comer, N., Young, I., Lammerding, A.M., \& Fazil, A. (2015). A risk modeling framework to evaluate the impacts of climate change and adaptation on food and water safety. Food Research International, 68(Februari), 78-85, https://doi.org/10.1016/j.foodres.2014.07.006.

Sweeney, J., Soutar, G., \& Johnson, L. (1999). The role of perceived risk in the quality-value relationship: A study in a retail environment. Journal of Retailing, 75(1), 77-105. https://doi.org/10.1016/S0022-4359(99)80005-0.

UKEssays. (November, 2018). Internal traceability and external traceability. https://www.ukessays.com/essays/information-technology/internal-traceability-and-externaltraceability-information-technology-essay.php?vref $=1$

Verbeke, W., \& Ward, R. W. (2006). Consumer interest in information cues denoting quality, traceability, and origin: An application of ordered probit models to beef labels. Food Quality and Preference, 17(6), 453-467. https://doi.org/10.1016/j.foodqual.2005.05.010

Widjaja, B. T. (2009). Lifestyle marketing. Gramedia Pustaka Utama 
World Health Organization [WHO]. (2015). World health statistics 2015. World Health Organization. https://apps.who.int/iris/handle/10665/170250

Wu, L., Xu, L., \& Gao, J. (2011). The acceptability of certified traceable food among Chinese consumers. British Food Journal, 113(4), 519-534. https://doi.org/10.1108/00070701111123998

Yeung, R. M. W., \& Morris, J. (2001). Food safety risk: Consumer perception and purchase behaviour. British Food Journal, 103(3), 170-187. https://doi.org/10.1108/00070700110386728

Yuan, C., Wang, S., \& Yu, X. (2020). The impact of food traceability system on consumer perceived value and purchase intention in China. Industrial Management \& Data Systems, 120(4), 810-824. https://doi.org/10.1108/IMDS-09-2019-0469

Zaichkowsky, J. L. (1985). Measuring the involvement construct. Journal of Consumer Research, 12(3), 341-352. https://www.jstor.org/stable/254378

Zhang, C., Bai, J., \& Wahl, T. (2012). Consumers' willingness to pay for traceable pork, milk, and cooking oil in Nanjing, China. Food Control, 27(1), 21-28, https://doi.org/10.1016/j.foodcont.2012.03.00

Zhang, Y., Jing, L., Bai, Q., Shao, W., Feng, Y., Yin, S., \& Zhang, M. (2018). Application of an integrated framework to examine Chinese consumers' purchase intention toward genetically modified food. Food Quality and Preference, 65(April), 118-128. https://doi.org/10.1016/j.foodqual.2017.11.001 